\title{
Remote Sensing Based Estimation of Evapo-Transpiration Using Selected Algorithms: The Case of Wonji Shoa Sugar Cane Estate, Ethiopia
}

\author{
Mulugeta Genanu $^{1} \quad$ Tena Alamirew $^{2} \quad$ Gabriel Senay $^{3} \quad$ Mekonnen Gebremichael $^{4}$ \\ 1. College of Natural Sciences Arba Minch University, Arba Minch, Ethiopia \\ 2. Water and Land Resource Centre, Addis Ababa University, Addis Ababa, Ethiopia \\ 3. USGS Earth Resources Observation and Science (EROS) Center, Sioux Falls, SD, USA \\ 4. Civil and Environmental Engineering Department, University of California- Los Angeles, California, USA
}

\begin{abstract}
Remote sensing datasets are increasingly being used to provide spatially explicit large scale evapotranspiration (ET) estimates. The focus of this study was to estimate and thematically map on a pixel-by-pixel basis, the actual evapotranspiration $\left(E_{\mathrm{a}}\right.$ ) of the Wonji Shoa Sugarcane Estate using the Surface Energy Balance Algorithm for Land (SEBAL), Simplified Surface Energy Balance (SSEB) and Operational Simplified Surface Energy Balance (SSEBop) algorithms. The results obtained revealed that the ranges of the daily ETa estimated on January 25, February 26, September 06 and October 08, 2002 using SEBAL were $0.0-6.85,0.0-9.36,0.0-3.61,0.0-$ $6.83 \mathrm{~mm} /$ day; using SSEB $0.0-6.78,0.0-7.81,0.0-3.65,0.0-6.46 \mathrm{~mm} /$ day, and SSEBop were $0.05-8.25$, $0.0-8.82,0.2-4.0,0.0-7.40 \mathrm{~mm} /$ day, respectively. The Root Mean Square Error (RMSE) values between SSEB and SEBAL, SSEBop and SEBAL, and SSEB and SSEBop were $0.548,0.548$, and 0.99 for January 25 , 2002; 0.739, 0.753, and 0.994 for February 26, 2002;0.847, 0.846, and 0.999 for September 06, 2002; 0.573, 0.573 , and 1.00 for October 08,2002 , respectively. The standard deviation of $\mathrm{ET}_{\mathrm{a}}$ over the sugarcane estate showed high spatio-temporal variability perhaps due to soil moisture variability and surface cover. The three algorithm results showed that well watered sugarcane fields in the mid-season growing stage of the crop had higher $\mathrm{ET}_{\mathrm{a}}$ values compared with the other dry agricultural fields confirming that they consumptively use more water. Generally during the dry season, $\mathrm{ET}_{\mathrm{a}}$ is limited to water surplus areas only and in wet season, $\mathrm{ET}_{\mathrm{a}}$ was high throughout the entire sugarcane estate. The evaporation fraction $(\mathrm{ETrF})$ results also followed the same pattern as the daily $\mathrm{ET}_{\mathrm{a}}$ over the sugarcane estate. The total crop and irrigation water requirement and effective rainfall estimated using the Cropwat model were 2468.8, 2061.6 and $423.8 \mathrm{~mm} / \mathrm{yr}$ for January 2001 planted and 2281.9, 1851.0 and $437.8 \mathrm{~mm} / \mathrm{yr}$ for March 2001 planted sugarcanes, respectively. The mean annual $\mathrm{ET}_{\mathrm{a}}$ estimated for the whole estate were $107 \mathrm{Mm}^{3}, 140 \mathrm{Mm}^{3}$, and $178 \mathrm{Mm}^{3}$ using SEBAL, SSEB, and SSEBop, respectively. Even though the algorithms should be validated through field observation, they have potential to be used for effective estimation of ET in the sugarcane estate.
\end{abstract}

Keywords: ET; CWR; Landsat ETM+; Remote Sensing; SEBAL; SSEB; SSEBop

\section{Introduction}

Water is one of the most important limited natural resources crucial for all socio-economic and environmental needs. It should be managed in a sustainable way to ensure its long-term availability. Judicious management of precious land and water resources is emerging as one of the biggest challenges of the $21^{\text {st }}$ century. Both water and land resources are finite, and competitive demand from other sectors is increasing. Therefore, water management for multiple benefits and between competing demands is occupying the minds of irrigators, catchment water managers and policy-makers. Irrigated agriculture is by far the largest consumptive water user sector and the goal of every grower is to practice irrigation management to fulfill water needs profitably, safely, and in an environmentally responsible way. Irrigation depends on reliable supplies of fresh, clean water from surface and/or groundwater sources. Knowing how much water moves through soils and crop canopy can help growers use irrigation water more effectively with less risk to water sources.

As stated by $[1,2]$, ET is a process governed by the energy and heat exchanges at the land surface, with the upper bound being constrained and controlled by the amount of available energy and water, respectively. ET is also an important factor for evaluating water productivity and monitoring of irrigation performance. Therefore, an estimation of spatially distributed crop water consumption is challenging, but important to determine water balance at different scales to promote efficient management of water resources. ET from irrigated agriculture is an important issue in arid and semi-arid regions where ET has large impact on water resources depletion and water management [3]. Accurate determination of crop ET is essential for designing irrigation systems and for irrigation scheduling. It is difficult, however, to accurately quantify ET directly. There are multiple methods for estimating ET for a drainage basin. The most widely used methods can be grouped into three categories, field insitu measurement, modeling approach and remote sensing technique [4]. ET measurement using in-situ measurements is expensive and only gives a point data. While, remote sensing data can resolve difficulties in 
determining water balance due to scientific developments in the calculation of spatially distributed actual ET $[5,6,7]$.

The remote sensing techniques are used to estimate ET and this is achieved by solving the energy balance of thermodynamics fluxes at the surface of the earth. It calculates the $\mathrm{ET}_{\mathrm{a}}$ based on the equilibrium between the radiation balance and the energy balance at the surface of the earth and its main advantage lies on its ability to provide spatial and temporal data instead of point data. Remote sensing can assist in improving the estimation of the geographical distribution of ET, and consequently water demand in large cultivated areas for irrigation purposes, water balance and sustainable water resources management. ET $_{\mathrm{a}}$ estimated using energy balance approach provides appropriate supply of irrigation water for the field based on the water requirement of the crop and could be useful for sustainable use of the available water resources.

In Ethiopia sugarcane, as the commercial crop and sugar factories are highly expanding to fulfill the local sugar market demand and beyond, to export for other countries. Ethiopian sugarcane estates are also expanding by increasing their farms to provide sufficient sugar cane production which could be used as an input for the factories industrial processing. Wonji Shoa sugarcane estate is the first large public irrigation scheme which is currently cultivating more than 9352 hectares of irrigated land using a furrow irrigation system. The present challenge for irrigated agriculture is to improve food security through more efficient and effective use of water. The consumptive use of water by crops $\mathrm{ET}_{\mathrm{a}}$ is only part of the total irrigation water supply from a river diversion or a reservoir. Measuring the ET is of highest importance for understanding and eventually intervening into the water cycle of natural systems, especially different critical users of water, like irrigated areas and their field crops. Understanding the amount of ET from water supply reservoirs and other storages is an important part of the water resource management. Accurate estimation of ET plays an important role in quantification of the water balance at the pixel, watershed, basin and regional scale for better planning and managing water resources.

Estimates of land surface ET using remote sensing data are essential in effective planning and management of irrigation water use in arid and semiarid regions. The remote sensing technology application is being rarely tested in Ethiopia, but it has not been applied to support crop ET, soil moisture and irrigation management practices from sugarcane estates because of the associated costs and quality of images. The current irrigation water management practice of Wonji Shoa sugarcane estate is poor and resulted in excessive loss of water resources and soil salinity problems. Satellite based measurements used in association with energy balance models can provide the spatial distribution of ET and used to derive maps of $\mathrm{ET}_{\mathrm{a}}$ with reasonable accuracy. Hence, the general aim of this study is to produce actual evapotranspiration estimates and to address some issues related to the management of irrigation water using the combination of SEBAL, SSEB, and SSEBop approach with representative ground meteorological station data and remotely-sensed Landsat ETM+ imagery and reference ET over Wonji Shoa irrigated sugarcane estate.

The main objectives of this study were:

- To estimate ET $_{\mathrm{a}}$ using Surface Energy Balance Algorithm for Land (SEBAL), Simplified Surface Energy Balance (SSEB), Operational Simplified Surface Energy Balance (SSEBop); and PenmanMonteith Methods;

- To compare the actual ET results of SEBAL, SSEBop and SSEB; and

- To calculate the crop water requirement of the sugarcane estate

\section{Materials and Methods}

2.1. Description of the Study Area

The Wonji-Shoa Sugarcane Estate lies downstream of the Koka Dam in the Central Rift Valley of Ethiopia in the upper Awash River basin around $114 \mathrm{~km}$ from Addis Ababa within the geographical boundaries of $8^{0} 21^{\prime}$ to $8^{0}$ $29^{\prime} \mathrm{N}$ latitudes and $39^{\circ} 12^{\prime}$ to $39^{\circ} 18^{\prime} \mathrm{E}$ longitudes at an altitude of about $1,540 \mathrm{~m}$ above sea level [8]. Currently the estate is cultivating more than 9352 hectares of irrigated land using furrow irrigation system.

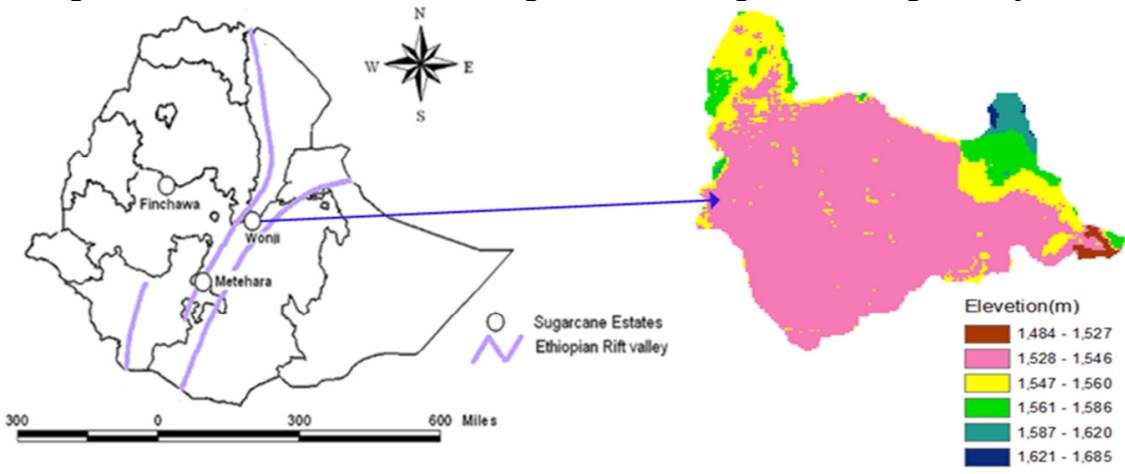

Figure 1. Location and topographic map of the study area 
In the estate, generally, the topography of the farm has gentle slopes with flood prone plains of Awash River. The soils of Wonji-Shoa have been described predominantly as a complex of gray, cracking clays in the topographic depressions and semiarid, brown soils. The main crops cultivated are sugarcane, haricot bean and crotalaria. Sugarcane is planted at a rate of 16-18 t/ha in the estate and it is cultivated as perennial monocrop. The mean annual relative humidity ranges from 43.2 to $68.4 \%$. The main rain season of the area is June to September. It is described as tropical wet climate with uniform warmth throughout the year and receives an average annual rainfall of $831.2 \mathrm{~mm}$, average daily potential ET of $4.5 \mathrm{~mm} /$ day, mean annual maximum and minimum temperatures of $27.6{ }^{\circ} \mathrm{C}$ and $15.2{ }^{\circ} \mathrm{C}$, respectively. The average sunshine hour is 9 hours in dry summer and 6.5 hours in August as cited in [9]. At Wonji, in the Upper Valley, the mean annual potential ET is $1810 \mathrm{~mm}$, over twice the mean annual rainfall [10].

\subsection{Descriptions of Energy Balance Models}

\subsubsection{Image Analysis for SEBAL Parameter Extraction}

The original satellite images were properly prepared for use in SEBAL, SSEB and SSEB ${ }_{\text {op }}$ algorithms and were applied to Landsat-7 ETM+ data for assessing the actual ET by calculating the ET flux for each pixel of the satellite image as a residual of the surface energy balance equation. Having estimated the land surface parameters such as Normalized Difference Vegetation Index (NDVI), surface albedo, reflectance, emissivity and temperature, the selected algorithms were employed to estimate daily actual ET. The NDVI is the ratio of the differences in reflectivities for the near-infrared band and the red band to their sum. The NDVI is a sensitive indicator of the amount and condition of green vegetation. Values for NDVI range between -1 and +1 . Green surfaces have a NDVI between 0 and 1 and water and cloud are usually less than zero. The land surface parameters in SEBAL were computed using Allen et al.(2002), [11] methodology. The first step used in the SEBAL procedure was to compute the net surface radiation flux $\left(R_{n}\right)$ using the surface radiation balance equation.

$$
R_{n}=(1-\alpha) R_{S \downarrow}+R_{L \downarrow}-R_{L \uparrow}-(1-\varepsilon) R_{L \downarrow}
$$

Where $R_{S \downarrow}$ is incoming shortwave radiation $\left(\mathrm{W} / \mathrm{m}^{2}\right), \alpha$ is broadband surface albedo (dimensionless), $\mathrm{R}_{\mathrm{L} \downarrow}$ is incoming long wave radiation $\left(\mathrm{W} / \mathrm{m}^{2}\right), R_{L \uparrow}$ is outgoing long wave radiation $\left(\mathrm{W} / \mathrm{m}^{2}\right), \varepsilon$ is surface thermal emissivity (dimensionless), $\mathrm{R}_{\mathrm{n}}$ represents the actual radiant energy available at the surface.

The amount of shortwave radiation (RS $\downarrow$ ) that remains available at the surface is a function of the surface albedo $(\alpha)$. Surface albedo is a reflection coefficient defined as the ratio of the reflected radiant flux to the incident radiant flux over the solar spectrum. It was calculated using satellite image information on spectral radiance for each satellite band. The incoming shortwave radiation (RS $\downarrow$ ) was computed using the solar constant, the solar incidence angle, a relative earth-sun distance, and a computed atmospheric transmissivity. The incoming longwave radiation ( $R L \downarrow$ ) was computed using a modified Stefan-Boltzmann equation with atmospheric transmissivity and a selected surface reference temperature. Outgoing longwave radiation (RL $\uparrow$ ) was computed using the Stefan-Boltzmann equation with a calculated surface emissivity and surface temperature. Surface temperatures were computed from satellite image information on thermal radiance. The surface emissivity is the ratio of the actual radiation emitted by a surface to that emitted by a black body at the same surface temperature. In SEBAL, emissivity was computed as a function of a vegetation index. The final term in Equation (1), (1-E)RL $\downarrow$, represents the fraction of incoming longwave radiation that is lost from the surface due to reflection.

The soil heat flux $(\mathrm{G})$ and sensible heat flux $(\mathrm{H})$ are subtracted from the net radiation flux at the surface $(\mathrm{Rn})$ to compute the residual energy available for evapotranspiration $(\lambda E T)$. Soil heat flux was empirically calculated using vegetation indices, surface temperature, and surface albedo. Sensible heat flux wass computed using wind speed observations, estimated surface roughness, and surface to air temperature differences. An iterative process to correct atmospheric instability due to the buoyancy effects of surface heating was done in SEBAL. Once the latent heat flux ( $\lambda \mathrm{ET}$ ) was computed for each pixel, an equivalent amount of instantaneous ET $(\mathrm{mm} / \mathrm{hr})$ was readily calculated by dividing by the latent heat of vaporization $(\lambda)$. These values are then extrapolated using a ratio of ET to reference crop ET to obtain daily ET. Reference crop ET is the ET rate expected from a well-defined surface of full-cover alfalfa or clipped grass and was computed in the SEBAL process using ground weather data. SEBAL can compute ET for flat agricultural areas with the most accuracy and confidence. The land surface temperature $\left(\mathrm{T}_{\mathrm{s}}\right)$ is computed using the following modified Plank equation and hot and cold pixels were selected.

$$
\mathrm{T}_{\mathrm{s}}=\frac{\mathrm{K}_{2}}{\ln \left(\frac{\varepsilon \times \mathrm{K}_{1}}{\mathrm{R}_{\mathrm{c}}}+1\right)}
$$

Where $R_{c}$ is the corrected thermal radiance from the surface which was calculated following [12], using the spectral radiance of band 6. $\mathcal{E}$ is the "broad-band" surface emissivity (dimensionless). Surface emissivity is the ratio of the thermal energy radiated by the surface to the thermal energy radiated by a blackbody at the same 
temperature and in SEBAL, it was computed as a function of NDVI following the methodology pointed by [13]. $\mathrm{K}_{1}$ and $\mathrm{K}_{2}$ are constants for Landsat images. The SEBAL process utilizes the "hot" and "cold" pixels to fix boundary conditions for the energy balance. The "cold" pixel is selected as a wet, well-irrigated crop surface having full ground cover by vegetation. The "hot" pixel is selected as a dry, bare agricultural field where ET is assumed to be zero [14].

Estimation of the Fluxes in the Surface Energy Balance Equation: the second step of the SEBAL procedure is to compute the terms soil heat flux $(\mathrm{G})$ and sensible heat flux $(\mathrm{H})$ of the surface energy budget equation as a function of net radiation flux $\left(\mathrm{R}_{\mathrm{n}}\right)$ as follows:

$$
\mathrm{R}_{\mathrm{n}}=\mathrm{G}+\mathrm{H}+\lambda \mathrm{ET}
$$

Where $R_{n}$ is the net radiation at the surface $\left(W / m^{2}\right), G$ is the soil heat flux $\left(W / m^{2}\right), H$ is the sensible heat flux to the air $\left(\mathrm{W} / \mathrm{m}^{2}\right)$, and $\lambda \mathrm{ET}$ is the latent heat flux $\left(\mathrm{W} / \mathrm{m}^{2}\right)$.

Soil Heat Flux $(G)$ : SEBAL first computes the ratio $G / R_{n}$ using the following empirical equation developed by [15], representing values near midday:

$$
\frac{G}{R_{n}}=\frac{\left(T_{s}-273\right)}{\alpha}\left(0.0038 \alpha+0.0074 \alpha^{2}\right)\left(1-0.98 N D V I^{4}\right)
$$

Where Ts is the surface temperature $\left({ }^{\circ} \mathrm{C}\right), \alpha$ is the surface albedo, and NDVI is the Normalized Difference Vegetation Index. $G$ is then readily calculated by multiplying $G / R_{n}$ by the value for $R_{n}$. Sensible Heat Flux $(\mathrm{H})$ : The sensible heat flux $(\mathrm{H})$ was computed using equation (5).

$$
\mathrm{H}=\frac{\rho \times \mathrm{c}_{\mathrm{p}} \times \mathrm{dT}}{\mathrm{r}_{\mathrm{ah}}}
$$

Where $\rho$ is air density $\left(\mathrm{kg} / \mathrm{m}^{3}\right), \mathrm{C}_{\mathrm{p}}$ is air specific heat $(1004 \mathrm{~J} / \mathrm{kg} / \mathrm{K})$, dT $(\mathrm{K})$ is the temperature difference $\left(T_{1}-T_{2}\right)$ between two heights $\left(z_{1}\right.$ and $\left.z_{2}\right)$, and $r_{a h}$ is the aerodynamic resistance to heat transport $(\mathrm{m} / \mathrm{s})$. Equation (5) is difficult to solve because there are two unknowns, $r_{a h}$ and dT. To facilitate this computation, the two "anchor" pixels (where reliable values for $\mathrm{H}$ can be predicted and a dT estimated) and the wind speed at a given height were utilized.

Latent Heat Flux $(\lambda E T)$, Instantaneous ET $\left(\mathrm{ET}_{\text {inst }}\right)$, and Reference ET Fraction $\left(\mathrm{ET}_{\mathrm{r}} \mathrm{F}\right)$ : In SEBAL mode latent heat flux is computed as residual variables of the energy balance equation as computed in Equation (3). $\lambda E T$ is an instantaneous value for the time of the satellite overpass $\left(\mathrm{W} / \mathrm{m}^{2}\right)$.

An instantaneous value of ET in equivalent evaporation depth was computed as:

$$
\text { ETinst }=3600 \frac{\lambda \mathrm{ET}}{\lambda}
$$

Where is the instantaneous ET ( $\mathrm{mm} / \mathrm{hr}), 3600$ is the time conversion from seconds to hours, and $\lambda$ is the latent heat of vaporization or the heat absorbed when a kilogram of water evaporates $(\mathrm{J} / \mathrm{kg})$. The reference ET Fraction $\left(\mathrm{ET}_{\mathrm{r}} \mathrm{F}\right)$ was computed using $\mathrm{ET}_{\text {inst }}$ and weather data.

$$
\mathrm{ETrF}=\frac{\text { ETinst }}{\mathrm{ET}_{\mathrm{o}}}
$$

Where $\mathrm{ET}_{\text {inst }}$ is from Equation $6(\mathrm{~mm} / \mathrm{hr})$ and $\mathrm{ET}_{\mathrm{o}}$ is the reference ET at the time of the image from the CROPWAT software $(\mathrm{mm} / \mathrm{hr}) . \mathrm{ET}_{\mathrm{r}} \mathrm{F}$ is similar to the well-known crop coefficient, $\mathrm{K}_{\mathrm{c}}$ and is used to extrapolate ET from the image time to 24-hour or longer periods.

Daily (24-Hour) Evapotranspiration $\left(\mathrm{ET}_{24}\right)$ : SEBAL computes the $\mathrm{ET}_{24}$ by assuming that the instantaneous $\mathrm{ET}_{\mathrm{r}} \mathrm{F}$ computed above is the same as the 24-hour average and ET varies throughout the day while $\mathrm{ET}_{\mathrm{r}} \mathrm{F}$ is relatively constant. Finally, the $\mathrm{ET}_{24}(\mathrm{~mm} /$ day) can be computed as:

$$
\mathrm{ET}_{24}=\mathrm{ETrF} \times \mathrm{ET}_{\mathrm{o}-24}
$$

Where $\mathrm{ET}_{\mathrm{o}-24}$ is the cumulative 24-hour $\mathrm{ET}_{\mathrm{o}}$ for the day of the image.

\subsubsection{Image Analysis for SSEB Parameter Extraction}

The main concept of the SSEB approach [16], is the joint use of reference ET and land surface temperature data. The surface energy balance is first solved for a reference crop condition (assuming full vegetation cover and unlimited water supply) using the standardized Penman-Monteith equation [17]. ET fractions (ETf) account for differences in water availability in the landscape; and are used to adjust the reference ET $\left(\mathrm{ET}_{\mathrm{o}}\right)$ based on the land surface temperature $\left(\mathrm{T}_{\mathrm{s}}\right)$ of the pixel (Eq. (2) for ETf). The ET fraction (ETf) is calculated for each pixel " $\mathrm{x}$ " by applying Eq. (10) to each of the 4-date Landsat $\mathrm{T}_{\mathrm{s}}$ grids.

$$
\mathrm{ETf}=\frac{\mathrm{TH}-\mathrm{Tx}}{\mathrm{TH}-\mathrm{TC}}
$$


where TH and TC are the average radiometric surface temperature at hot and cold pixels, respectively; and $\mathrm{Tx}$ is the radiometric surface temperature for any given pixel in that image. The basic approach of calculating ETa involves only two steps: ETa is simply a product of the ET fraction (ETf) and ET $_{\mathrm{o}}$ via Equation (11) and (12).

$$
\mathrm{ETa}=\mathrm{ETf} \times \mathrm{ETm}
$$

where ETa is actual ET, ETf is ET fraction, and ETm is maximum ET for the region. When grass reference ETo is calculated from weather data, ETm is estimated as:

$$
\mathrm{ETm}=\alpha \times \mathrm{ET}_{\mathrm{o}}
$$

where the multiplier $\alpha$ is recommended to be 1.2 to estimate ET for tall, full cover crops such as alfalfa, corn, sugarcane and wheat which are aerodynamically rougher than the clipped grass reference and have greater leaf area and thus greater canopy conductance [17].

2.2.3 Image Analysis for $\mathrm{SSEB}_{\mathrm{op}}$ Parameter Extraction

The method is developed by [18], and it is based on the Simplified Surface Energy Balance (SSEB) approach

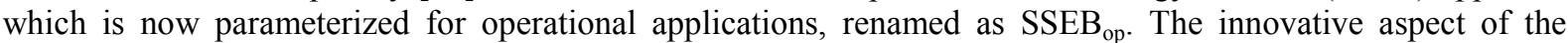
$\mathrm{SSEB}_{\text {op }}$ parameterization is that it uses pre-defined, boundary conditions that are unique to each pixel for the "hot" and "cold" reference conditions. To estimate ET routinely, the only data needed for this method are $\mathrm{T}_{\mathrm{s}}$, climatology air temperature $\left(\mathrm{T}_{\mathrm{a}}\right)$ and $\mathrm{ET}_{\mathrm{o}}$. With this simplification, actual ET $\left(\mathrm{ET}_{\mathrm{a}}\right)$ is estimated using equation 13 as a fraction of the $\mathrm{ET}_{\mathrm{o}}$ and the ET fraction (ETf) is calculated using equation 14.

$$
\mathrm{ETa}=\text { ETf } \times \alpha \text { ETo }
$$

Where $\mathrm{ET}_{\mathrm{o}}$ is the grass reference ET; $\alpha$ is a crop coefficient with a recommended value of 1.2.

$$
\operatorname{ETf}=\frac{\mathrm{T}_{\mathrm{h}}-\mathrm{T}_{\mathrm{s}}}{\mathrm{T}_{\mathrm{h}}-\mathrm{T}_{\mathrm{c}}}
$$

Where $T_{\mathrm{s}}$ is the satellite observed land surface temperature of the pixel whose ETf is being evaluated on a given time-period. $\mathrm{T}_{\mathrm{h}}$ is the estimated $\mathrm{Ts}$ at the idealized reference "hot" condition of the pixel, the cold reference value Tc, is the estimated $T s$ at the idealized reference "cold" condition of the pixel of the same time period.

$\mathrm{T}_{\mathrm{c}}$ determination: $\mathrm{T}_{\mathrm{c}}$ boundary condition was determined using correction coefficient as :

$$
\mathrm{T}_{\mathrm{c}}=\mathrm{c} \times \mathrm{T}_{\mathrm{a}}
$$

Where $\mathrm{T}_{\mathrm{a}}$ is the climatology near-surface maximum $\mathrm{T}_{\mathrm{a}}$ for the period; $\mathrm{c}$ is a correction factor that relates $\mathrm{T}_{\mathrm{a}}$ to $\mathrm{T}_{\mathrm{s}}$ on a well-watered, fully transpiring vegetation surface. The correction coefficient $\mathrm{c}$ is determined as a seasonal average between $T_{s}$ and $T_{a}$ on all pixels where NDVI is greater or equal to 0.8 . Preliminary results showed that this coefficient vary little from place to place. However, for localized applications, one is advised to develop local specific 'c' values.

$$
\mathrm{c}=\frac{\mathrm{T}_{\text {scold }}}{\mathrm{T}_{\mathrm{a}}}
$$

Where $\mathrm{T}_{\text {scold }}$ is the satellite-based $\mathrm{T}_{\mathrm{s}}$ at the cold pixel where NDVI $>0.8$ and $\mathrm{T}_{\mathrm{a}}$ is the corresponding air temperature at same location and season. The correction factor for the study area was determined to be 0.989 when both $T_{s}$ and $T_{a}$ were processed in Kelvin units which is calculated as the spatially averaged values of available locations and is usually obtained in peak-season irrigated areas and forested regions.

Pre-defined dT and hot boundary condition: Once the $T_{c}$ is defined as the fraction of the climatological $\mathrm{T}_{\mathrm{a}}$, the hot boundary condition $\left(\mathrm{T}_{\mathrm{h}}\right)$ can also be defined by a constant difference (dT) that will be added to the $\mathrm{T}_{\mathrm{c}}$ of each pixel on a given time period. Thus, the second key component of this method is estimation of dT from energy balance principles for a clear sky condition. The pre-defined dT is solved from the Rn equation solved for a bare, dry soil where ET is assumed to be zero and sensible heat is assumed maximum [19]. Since $\lambda$ ET and $G$ are considered 0.0, the magnitude of the radiation balance for a bare, dry soil with the sensible heat equation can be written as follows:

$$
\mathrm{Rn}=\mathrm{H}=\mathrm{p} \times \mathrm{c}_{\mathrm{p}} \times \mathrm{dT} / \mathrm{r}_{\mathrm{a}}
$$

Since all $\mathrm{Rn}$ is now assumed to be used for sensible heat flux at the hot boundary condition, $\mathrm{H}$ will be approximated by the clear-sky net radiation received at an idealized bare and dry surface for a given pixel on a given period. The next step is to estimate the available clear-sky net radiation that is available for a given period so that $\mathrm{dT}$ can be solved by rearranging Equation 17. After $\mathrm{R}_{\mathrm{n}}$ is estimated for each pixel, the pre-defined dT was solved using $\mathrm{R}_{\mathrm{n}}, \mathrm{c}_{\mathrm{p}}$ and $\rho$ and $\mathrm{r}_{\mathrm{a}}$ as:

$$
\mathrm{dT}=\frac{\mathrm{R}_{\mathrm{n}} \times \mathrm{r}_{\mathrm{a}}}{\rho \times \mathrm{c}_{\mathrm{p}}}
$$


Where $c_{p}$ is the specific heat of air at constant pressure $\left(1.013 \mathrm{~kJ} \mathrm{~kg}^{-1}{ }^{\circ} \mathrm{C}^{-1}\right)$; $\rho$ is the density of air which is calculated using [17], $\mathrm{r}_{\mathrm{a}}$ is the aerodynamic resistance to heat flow from a hypothetical bare and dry surface; it was determined through a quasi-calibration process. Furthermore, comparison with 45 US flux tower ET by [20], shows that $110 \mathrm{~ms}^{-1}$ gives a reasonable agreement and decided in this study to fix the $\mathrm{r}_{\mathrm{a}}$ value at $110 \mathrm{~ms}^{-1}$.

Therefore, once the expected dT is determined, Th was calculated as follows:

$$
\mathrm{Th}=\mathrm{Tc}+\mathrm{dT}
$$

\subsection{Methods of Crop Evapotranspiration $\left(\mathrm{ET}_{\mathrm{c}}\right)$ Estimation}

CROPWAT is a decision support system developed by the Land and Water Development Division of FAO for planning and management of irrigation. CROPWAT was used as a practical tool to carry out standard calculations for reference ET, crop water requirements and crop irrigation requirements, and more specifically the design and management of irrigation schemes. It allows the development of recommendations for improved irrigation practices, the planning of irrigation schedules under varying water supply conditions, and the assessment of production under rainfed conditions or deficit irrigation. Calculations of the $\mathrm{ET}_{\mathrm{o}}$, crop water requirements and irrigation requirements are carried out with inputs of climatic, crop and soil data.

The Food and Agricultural Organization (FAO) Penman-Monteith method was used as the sole method for determining $\mathrm{ET}_{\mathrm{o}}$ and explicitly incorporates both physiological and aerodynamic parameters. ETc is calculated by multiplying $\mathrm{ET}_{\mathrm{o}}$ by $\mathrm{K}_{\mathrm{c}}$, a coefficient expressing the difference in evapotranspiration between the cropped and reference grass surface. In this study the difference were combined into one single coefficient that means the effect of crop transpiration and soil evaporation are combined into a single $\mathrm{K}_{\mathrm{c}}$ coefficient. The Crop Water Requirements (CWR) were calculated on the basis of monthly effective rainfall $\left(\mathrm{P}_{\mathrm{eff}}\right)$ and $\mathrm{ET}_{\mathrm{o}}$, the first being calculated from average rainfall following the Penman-Monteith approach.

$$
E T_{c}=K_{c} \times E T_{o}
$$

Where $\mathrm{ET}_{\mathrm{c}}$ crop ET $\left(\mathrm{mm} \mathrm{d}^{-1}\right), \mathrm{K}_{\mathrm{c}}$ crop coefficient (dimensionless), $\mathrm{ET}_{\mathrm{o}}$ reference crop ET $\left(\mathrm{mm} \mathrm{d}^{-1}\right)$.

\subsection{Data Collection and Analysis}

\subsubsection{Remote Sensing Data}

The main remote sensing input used for this study is Landsat7 ETM+ data having spatial resolution of 30m for visible and near infrared bands ( $\mathrm{b} 1$ to $\mathrm{b} 5$ and b7) and 60m resolution for thermal band (b61 and b62) at satellite nadir provided by the United States Geological Survey (USGS) Earth Observation System (EOS) Data Gateway. Four relatively cloud free Landsat7 ETM+ images covering the entire study site (Path 168, Row 54) bounded by $8^{\circ} 24^{\prime} 20^{\prime \prime} \mathrm{N}$ and $39^{\circ} 16^{\prime} 2^{\prime \prime} \mathrm{E}$ in the period between January and October, 2002 were acquired and downloaded from the USGS website (http://edcsns17.cr.usgs.gov/EarthExplorer/) freely.

The Landsat ETM+ seven bands (Band1 to Band7) were layered inside ERDAS IMAGINE, in order from band 1 to band 7 to create an image file for use in the image analysis process and after that, a smaller subset image was created for Wonji Shoa sugarcane estate. The Landsat ETM+ images were first radiometrically calibrated and georeferenced to local projections to obtain land surface parameters such as NDVI, reflectance, emissivity and temperature. The original Landsat images were checked for geo-rectified for use in the algorithms with appropriate coordinates. The rectified images were saved in the GeoTIF format and the nearest neighborhood resembling was used during rectification to preserve spectral information. An atmospheric correction were applied to Landsat data since we have local values for several meteorological parameters based on NASA web page (http://atmcorr.gsfc.nasa.gov/) that provides local values for transmittance, upwelling radiance, and downwelling radiance for use in computation of corrected thermal radiance following [12], methodology. The satellite images were preprocessed and further processed to derive the land surface parameters as required by the energy balance models to derive ET. Having estimated the land surface parameters, the selected algorithms were employed to estimate daily actual ET using SEBAL, SSEB, and SSEBop algorithms.

2.4.2 Meteorological Data

The Meteorological data in daily time steps were collected from Wonji Shoa sugarcane estate research center weather station during the four satellite overpass dates as shown in table 1 below and used to calculate ETo using the FAO-Penman Monteith method with the help of CROPWAT software. The computed ETo here was used to calculate daily ETa. There were no missing meteorological data during the satellite overpass dates and average values for all meteorological parameters were used.

Table 1. Average/ daily weather conditions at the satellite overpass time

\begin{tabular}{|l|c|c|c|c|c|c|}
\hline Dates & Temperature $\left({ }^{\circ} \mathrm{C}\right)$ & Humidity $(\%)$ & $\begin{array}{l}\text { Wind speed at } \\
2 \mathrm{~m}(\mathrm{~m} / \mathrm{sec})\end{array}$ & $\begin{array}{l}\text { Actual sunshine } \\
\text { hour }\end{array}$ & $\begin{array}{l}\text { Precipitation } \\
(\mathrm{mour})\end{array}$ & $\begin{array}{l}\text { ETo Penman } \\
(\mathrm{mm})\end{array}$ \\
\hline Jan 25,2002 & 17.4 & 43 & 3.1 & 10.5 & 0.0 & 5.49 \\
\hline Feb 26,2002 & 20.5 & 36 & 2.8 & 11 & 0.0 & 6.31 \\
\hline Sept 6,2002 & 21.8 & 58 & 1.7 & 0.0 & 0.0 & 3.11 \\
\hline Oct 8,2002 & 19.4 & 46 & 2.4 & 11 & 0.0 \\
\hline
\end{tabular}




\section{Results and Discussions}

3.1 Spatial and Temporal Distribution of Evapotranspiration

The spatial and temporal variability of the $\mathrm{ET}_{\mathrm{a}}$ estimated using the SEBAL, SSEB, and SSEB op $_{\text {algorithms are }}$ presented and discussed in the following subsections. The satellite image had relatively good resolution $(30 \mathrm{~m}$ by $30 \mathrm{~m}$ ) which make the results more acceptable and in a good agreement with observed $\mathrm{ET}_{\mathrm{a}}$ values as indicated by the study findings of [21]. These models results actually have to be calibrated and validated using observed data and this is the limitation of the study due to lack of finance to buy and install in-situ measuring instruments over the sugarcane estate.

3.1.1 Spatial Distribution of $\mathrm{ET}_{\mathrm{a}}$ During January, 2002

The estimated daily minimum and maximum ET $_{\mathrm{a}}$ values in January using SEBAL, SSEB and SSEB ${ }_{\mathrm{op}}$ algorithms were 0.0 and $6.85,0.0$ and 6.78 , and 0.05 and $8.25 \mathrm{~mm}$ /day respectively with mean and standard deviation values of 2.88 and 1.41, 3.45 and 1.66, and 4.88 and 1.68 respectively (figure 2). According to SSEBop, SSEB and SEBAL ETa results more than $65 \%$ of the area exhibit nearly $3.6-8.2,3.0-6.8$, and $2.4-4.8 \mathrm{~mm} / \mathrm{day}$ respectively. Well watered sugarcane fields in the mid-season growing stage of the crop and water storage areas reveals higher ETa values compared to the other dry agricultural fields which indicated that they are more water user fields. ETa estimated over dry agricultural (uncultivated) fields using SSEBop, SSEB and SEBAL ranges from $0.0-2.6,0.0-2.2$, and $0.0-2.2 \mathrm{~mm}$ /day respectively. The ET loss in this month is higher than the monthly precipitation in the sugarcane plantation farm and irrigation water is the source for an optimum climatic condition to satisfy the evaporative demand of the area. This clearly demonstrated that the seasonal distribution of ET is related to the moisture availability and the surface types. Therefore it can be concluded that, during the dry season, ET were limited to the well watered sugarcane fields and water storage areas only, which were fed continuously from the irrigation.

Comparative assessment of standard deviation of $\mathrm{ET}_{\mathrm{a}}$ over the sugarcane plantation indicated moderate spatial variability of $\mathrm{ET}_{\mathrm{a}}$ due to soil moisture variability which itself is dependent on irrigation application and rainfall availability. Dry periods exhibit greater variability than wetter periods. The SEBAL algorithm $\mathrm{ET}_{\mathrm{a}}$ estimation on well irrigated moist sugarcane fields, water storage reservoirs including Awash River was higher than the other cultivated sugarcane plantation fields. It also showed that no moisture was lost by ET in most of bare agricultural fields. SSEB and $\mathrm{SSEB}_{\mathrm{op}} \mathrm{ET}_{\mathrm{a}}$ estimation over moist and cultivated sugarcane fields were consistent and closer. The ET over some bare agricultural fields especially SSEB ${ }_{\text {op }}$ contradicted SEBAL results. All the three algorithm results showed that moist surfaces have higher $\mathrm{ET}_{\mathrm{a}}$ values. Moreover, dry agricultural fields exhibits generally lower $\mathrm{ET}_{\mathrm{a}}$ values. This shows that the remote sensing technique can capture the spatial variability of $\mathrm{ET}_{\mathrm{a}}$. The highest mean $\mathrm{ET}_{\mathrm{a}}$ values in the well watered sugarcane fields resulted due to mid-season stage crop developed through irrigation and in swamp of the plain and night water storage reservoirs. The residual difference of ETa estimated between SSEBop and SSEB looked consistent and good throughout the sugarcane estate with values in the range of $0.9-1.47$ and $0.05-0.89 \mathrm{~mm} /$ day over moist sugarcane fields and dry agricultural lands, respectively. The residual difference of ETa estimation between SSEBop and SEBAL ranged from $-1.18-5.53 \mathrm{~mm} /$ day, while between SSEB and SEBAL ranged nearly from $-2.59-4.08 \mathrm{~mm} / \mathrm{day}$. Generally higher residual $\mathrm{ET}_{\mathrm{a}}$ values were observed over well grown sugarcane fields and water storage areas and lower values were observed over dry agricultural fields. The Root Mean Square Error (RMSE) values between SSEB and SEBAL, SSEB ${ }_{\text {op }}$ and SEBAL, and SSEB and SSEB ${ }_{\text {op }}$ ET $_{\mathrm{a}}$ estimates were 0.548, 0.548, and 0.99 respectively. 

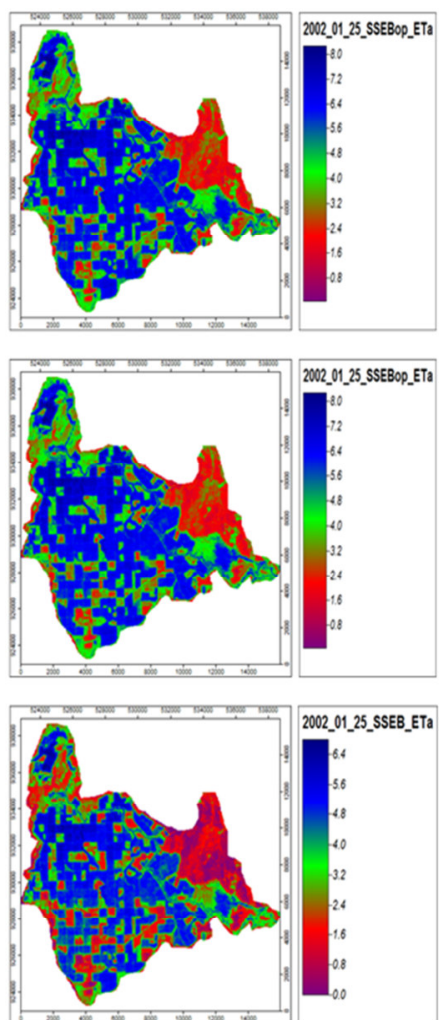
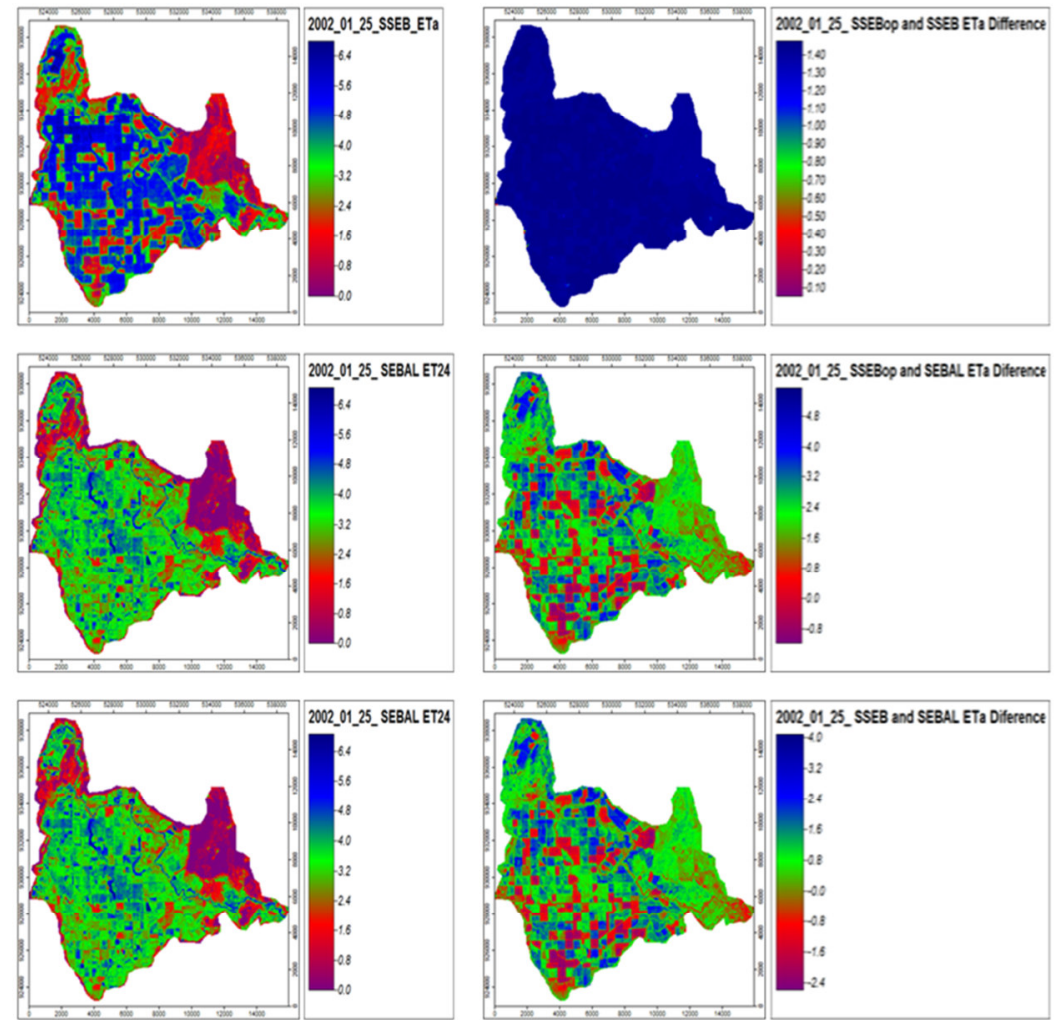

Figure 2. January 25, 2002 actual evapotranspiration (mm/day) at Wonji sugarcane estate

3.1.2 Spatial Distribution of $\mathrm{ET}_{\mathrm{a}}$ During February 26, 2002

The daily minimum and maximum $\mathrm{ET}_{\mathrm{a}}$ values of February 26, 2002 using SEBAL, SSEB and SSEB algorithms were found to be between 0.0 and $9.36,0.0$ and 7.81 , and 0.0 and $8.82 \mathrm{~mm} /$ day, respectively with mean and standard deviation values of 2.82 and $1.68,3.01$ and 2.13 , and 3.95 and $2.23 \mathrm{~mm} /$ day, respectively (figure 3). During February 26, 2002, 65\% of the area in the estate resulted in ETa values between 2.4 $8.8 \mathrm{~mm}$ /day for SSEBop, 2.2- 7.8mm/day for SSEB, and $2.4-5.8 \mathrm{~mm} /$ day for SEBAL. On the other hand ETa estimated over dry agricultural (uncultivated) fields were between $0.0-2.3 \mathrm{~mm} /$ day for SSEBop, 0.0 $2.1 \mathrm{~mm} /$ day, for SSEB, and $0.0-2.3 \mathrm{~mm}$ /day for SEBAL. During February, the atmospheric evaporative demands in the area were higher than that of January. The standard deviations of ETa over the sugarcane plantation were also higher indicating higher spatial variability of ETa due to soil moisture variability. All the three algorithms $\mathrm{ET}_{\mathrm{a}}$ estimates on well irrigated and moist sugarcane fields, water storage reservoirs including Awash River were higher than the uncultivated sugarcane plantation fields and bare agricultural fields. All the three algorithm results showed that well grown and well irrigated moist sugarcane fields in the mid-season growing stage and water storage areas exhibited higher ETa values compared to other dry agricultural fields. Generally it was noted that $\mathrm{SSEB}_{\mathrm{op}}$ and SSEB ET $\mathrm{F}_{\mathrm{a}}$ estimates were closer and consistent over fully covered and well grown sugarcane fields, and also were higher than SEBAL ET $\mathrm{a}_{\mathrm{a}}$ estimates. The SEBAL algorithm $\mathrm{ET}_{\mathrm{a}}$ estimates over water storage areas were higher than $\mathrm{SSEB}_{\text {op }}$ and $\mathrm{SSEB} \mathrm{ET}_{\mathrm{a}}$ estimates. On the contrary, SEBAL $\mathrm{ET}_{\mathrm{a}}$ estimates over uncultivated sugarcane fields were observed to be higher than $\mathrm{SSEB}_{\text {op }}$ and $\mathrm{SSEB}_{\mathrm{ET}}$ estimates. Over dry agricultural fields, the $\mathrm{ET}_{\mathrm{a}}$ estimates of all the three algorithms were close to each other. The residual difference of ETa estimation between SSEBop and SSEB looked consistent and good throughout the sugarcane estate with a value of $0.7-1.0$ and $0.0-0.6 \mathrm{~mm} /$ day over moist sugarcane fields and dry agricultural lands, respectively. On the other hand the SSEBop and SEBAL residual ranged from $-2.23-4.65 \mathrm{~mm} / \mathrm{day}$, while between SSEB and SEBAL residual varied between $-3.25-3.64 \mathrm{~mm} /$ day. Generally, higher residual values were observed over well grown sugarcane fields and water storage areas, but lower values were observed over dry agricultural fields. The Root Mean Square Error (RMSE) values of 0.739 between SSEB and SEBAL, 0.753 between $\mathrm{SSEB}_{\mathrm{op}}$ and SEBAL, and 0.994 between SSEB and $\mathrm{SSEB}_{\mathrm{op}} \mathrm{ET}_{\mathrm{a}}$ were observed. 

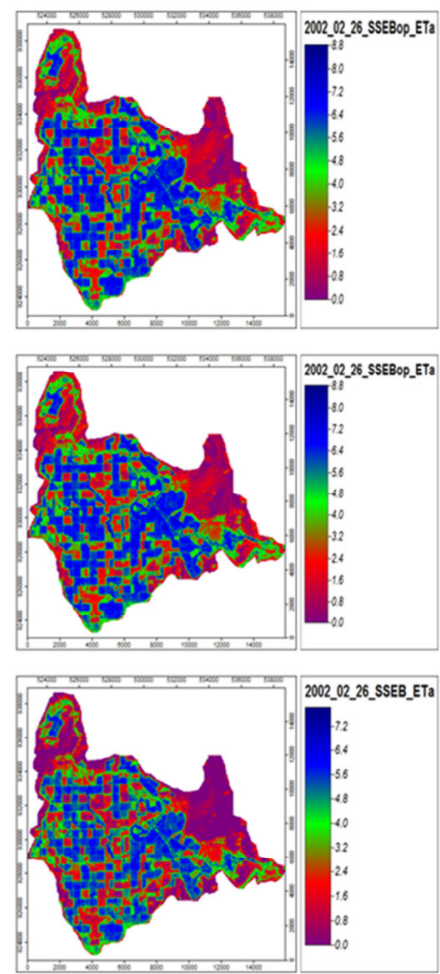
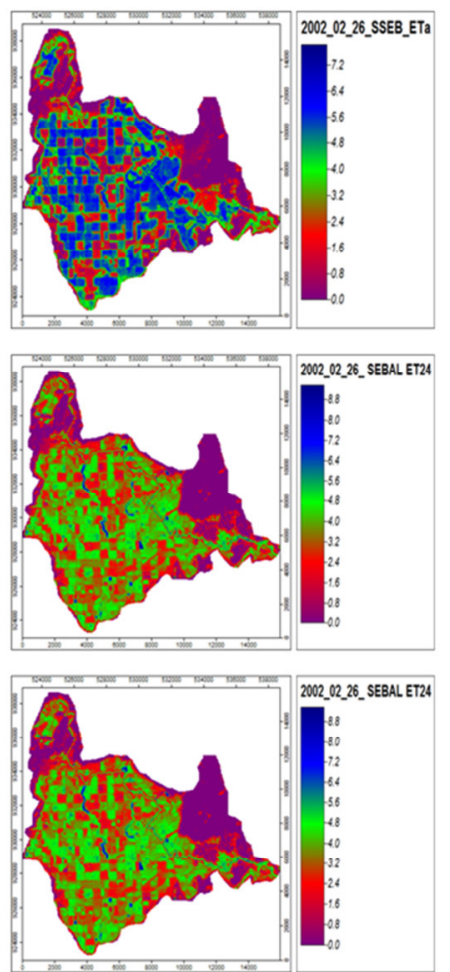
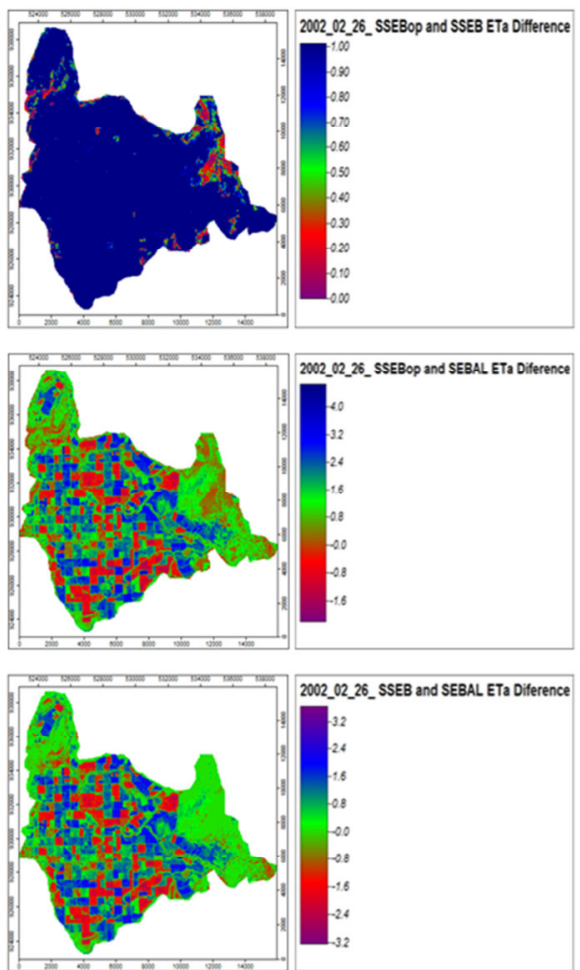

Figure 3. February 26, 2002 actual evapotranspiration ( $\mathrm{mm} /$ day) at Wonji sugar estate 3.1.3 Spatial Distribution of $\mathrm{ET}_{\mathrm{a}}$ During September 06, 2002

The September 06, 2002 minimum and maximum daily $\mathrm{ET}_{\mathrm{a}}$ values were 0.0 and $3.61 \mathrm{~mm} /$ day for SEBAL, 0.0 and $3.65 \mathrm{~mm} /$ day for SSEB and 0.2 and $4.0 \mathrm{~mm} /$ day for SSEB $_{\text {op }}$ algorithms (figure 4). The overall field average SEBAL, SSEB, and SSEBop mean (mm/day) values were 2.31, 2.46. 2.92, while the corresponding standard deviations were $0.43,0.7$, and 0.64 , respectively. All the three algorithms $\mathrm{ET}_{\mathrm{a}}$ estimates on well grown and moist sugarcane fields, night storage reservoirs and on the Awash River were higher than other dry agricultural fields. The comparisons with earlier months showed that more water was lost by $\mathrm{ET}_{\mathrm{a}}$ on bare agricultural (uncultivated) fields. This is expected as September is end of the rainy month and the soil should contain more moisture for subsequent ET, but generally all of the three algorithms $\mathrm{ET}_{\mathrm{a}}$ estimates were lower due to higher humidity and a decreased solar radiation associated with the effect cloud cover at the satellite overpass time. According to SSEBop, SSEB and SEBAL ETa results, more than $80 \%$ of the area exhibit nearly $2.4-4.0,2.2-3.65$, and $2.0-$ $3.61 \mathrm{~mm} /$ day, respectively. The ranges of ETa estimated over dry agricultural (uncultivated) fields using SSEBop, SSEB and SEBAL were respectively $0.2-2.3,0.0-2.1$, and $0.0-1.9 \mathrm{~mm} /$ day. During September, the optimum climatic condition to satisfy the evaporative demand of the area were higher than the other months except the cloud cover which resulted in lower $\mathrm{ET}_{\mathrm{a}}$ values throughout the sugarcane estate. The standard deviation of $\mathrm{ET}_{\mathrm{a}}$ over the sugarcane plantation were also lower indicating lower spatial variability of $\mathrm{ET}_{\mathrm{a}}$ due to less soil moisture variability. Even though the soil was saturated due to excess summer rainfall providing the opportunity for ample ET in the area, lower atmospheric demand (low radiant energy of the sun) due to cloud cover and higher humidity causes the entire sugarcane estate to have lower $\mathrm{ET}_{\mathrm{a}}$ values. The residual difference of ETa estimates between SSEBop and SSEB looks consistent and good throughout the sugarcane estate with values $0.50-0.69$ for moist sugarcane fields and $0.2-0.49 \mathrm{~mm} /$ day for dry agricultural lands of the estate. The residual difference of ETa estimates between SSEBop and SEBAL ranged from $-0.81-1.85 \mathrm{~mm} /$ day, while that of SSEB and SEBAL ranged from $-1.49-1.35 \mathrm{~mm} /$ day. In general, higher residual values were observed over well grown sugarcane fields and water storage areas, and lower values were observed over dry agricultural fields. $\mathrm{ET}_{\mathrm{a}}$ estimate for $\mathrm{SSEB}_{\mathrm{op}}$, SSEB and SEBAL during September were close to each other and looked consistent and higher over the entire sugarcane estate. Bare agricultural fields had also excess rainfall to evapo-transpire into the atmosphere. The Root Mean Square Error (RMSE) values were 0.847 for SSEB and SEBAL, 0.846 for

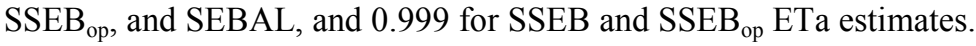



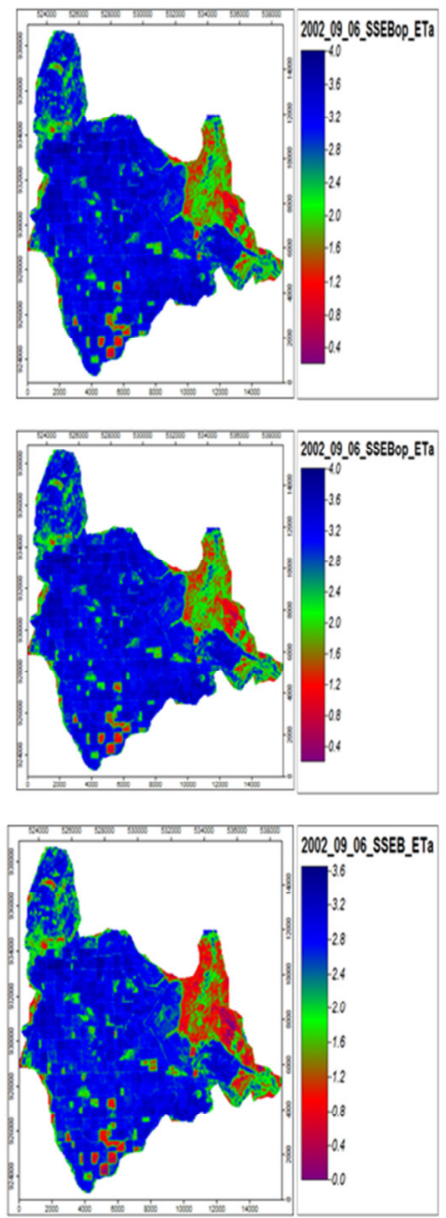
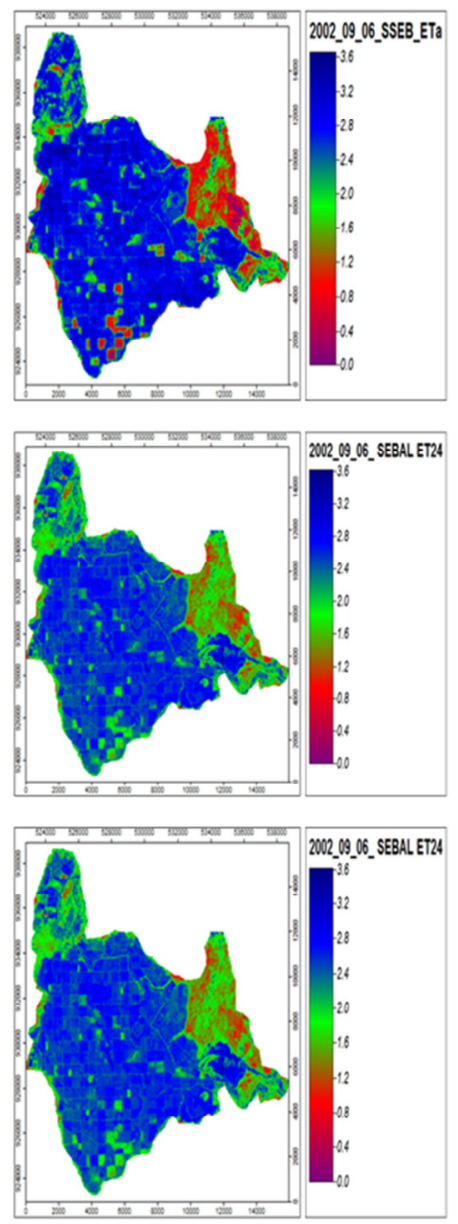
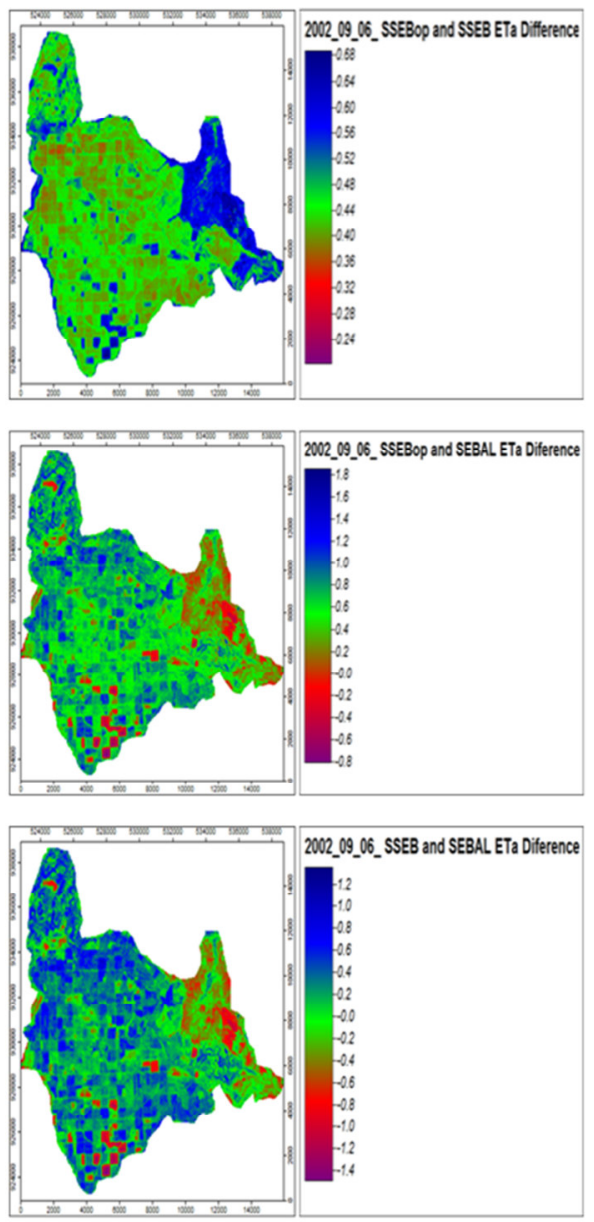

Figure 4. September 6, 2002 actual evapotranspiration (mm/day) at Wonji sugar estate

3.1.4 Spatial Distribution of $\mathrm{ET}_{\mathrm{a}}$ During October 8, 2002

The estimated daily minimum and maximum ET $_{\mathrm{a}}$ values on October 8,2002 using SEBAL, SSEB and SSEB op algorithms were 0.0 and 6.83, 0.0 and 6.46, and 0.0 and $7.4 \mathrm{~mm} /$ day, respectively (figure 5). The corresponding mean and standard deviation values respectively were 1.57 and 1.08 for SEBAL, 3.62 and 1.46 for SSEB, and 4.18 and 1.65 for $\mathrm{SSEB}_{\mathrm{op}}$. The SEBAL algorithm ETa estimates on well grown and moist sugarcane fields, night storage reservoirs and on the Awash River were higher than the other cultivated sugarcane plantation fields. It also showed that there were only little moisture losses by ET in most of bare agricultural (uncultivated) fields due to soil moisture stress. SSEB and SSEBop ETa estimation over water bodies, moist and cultivated sugarcane fields looked closer and consistent. The ETa values obtained on bare agricultural fields suggested that there were still adequate residual moisture from the preceding rainy months contributing to the overall evaporation. The $\mathrm{ET}_{\mathrm{a}}$ values obtained on bare agricultural fields suggested that there were still adequate residual moisture from the preceding rainy months contributing to the overall ET. All the three algorithm results consistently exhibited that moist surfaces have higher $\mathrm{ET}_{\mathrm{a}}$ values as compared to dry agricultural fields. The results on October 8, 2002 showed that $65 \%$ of the area in the estate had ETa values in the ranges of 3.2 - 7.4, 3.6- 6.46, and $1.2-4.5$ $\mathrm{mm}$ /day according to SSEBop, SSEB and SEBAL estimates, respectively. The ranges of ETa values estimated over dry agricultural (uncultivated) fields using SSEBop, SSEB and SEBAL algorithms were between 0.0 - 3.1, $0.0-3.5$, and $0.0-1.1 \mathrm{~mm} /$ day, respectively. During October 2002, the optimum climatic condition to satisfy the evaporative demand of the area were higher and the standard deviation of $\mathrm{ET}_{\mathrm{a}}$ over the sugarcane plantation were lower indicating lower spatial variability of $\mathrm{ET}_{\mathrm{a}}$ in relation to the soil moisture variability. Generally higher residual values are observed over well grown sugarcane fields and night storage areas, and lower values were observed over dry agricultural fields. The residual difference of $\mathrm{ET}_{\mathrm{a}}$ estimates between $\mathrm{SSEB}_{\mathrm{op}}$ and SSEB varied from $0.4-0.94$ on moist sugarcane fields, and $0.0-0.39 \mathrm{~mm} /$ day over dry agricultural lands. The ranges of the residual difference of $\mathrm{ET}_{\mathrm{a}}$ estimates between $\mathrm{SSEB}_{\text {op }}$ and SEBAL were $-1.29-5.98 \mathrm{~mm} /$ day, between SSEB and SEBAL were from $-1.7-5.2 \mathrm{~mm} /$ day. The Root Mean Square Error (RMSE) value between SSEB and SEBAL, SSEB ${ }_{\text {op }}$ and SEBAL, and SSEB and SSEB $_{\text {op }}$ ETa estimation were 0.573, 0.573, and 1.00, respectively. 

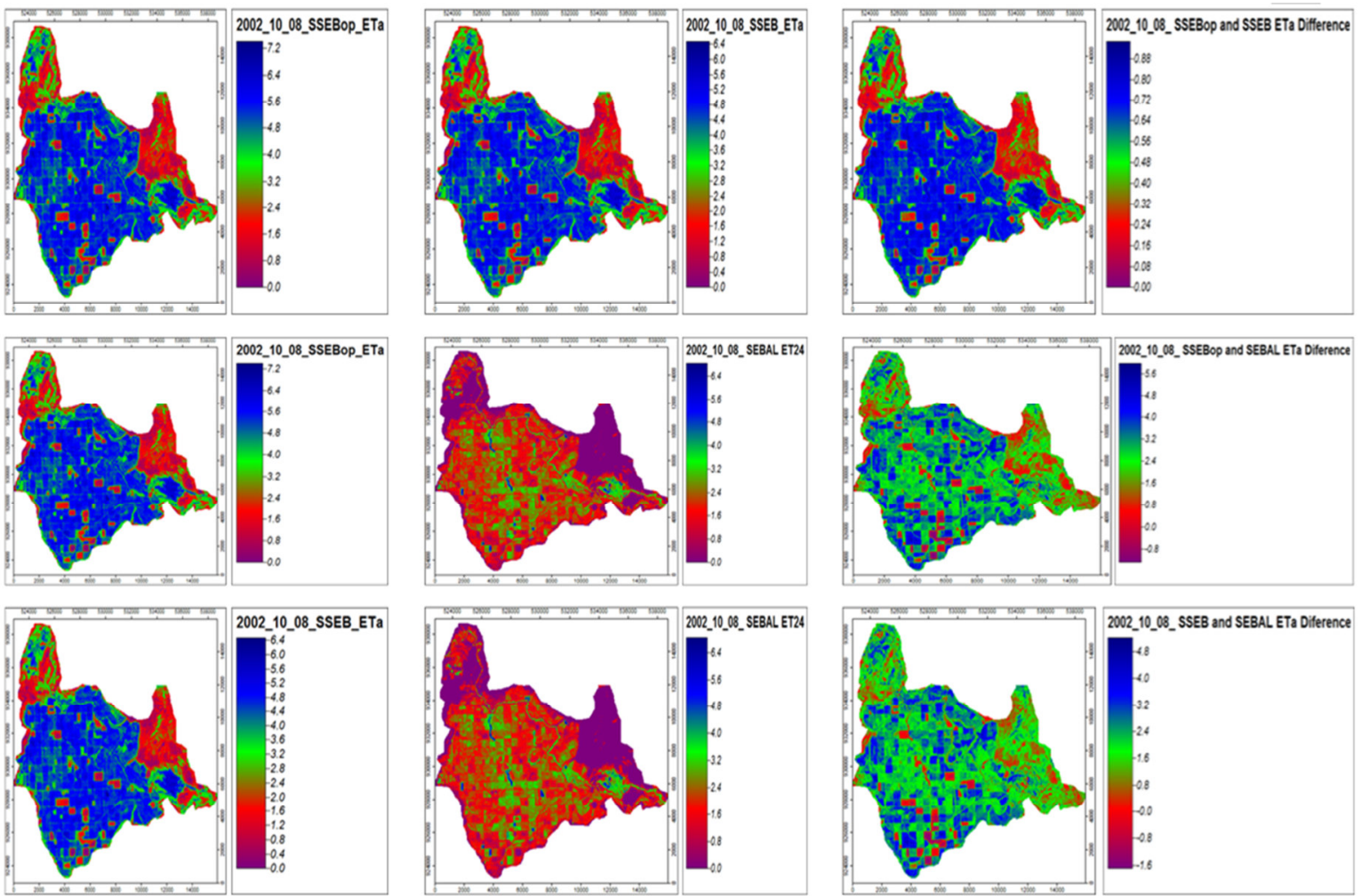

Figure 5. October 8, 2002 daily evapotranspiration (mm/day) at Wonji sugar estate

3.2 Crop and Irrigation Water Requirement (CWR)

As shown in Table 2 below, estimates of the average annual water consumption by SSEB $_{\text {op }}$ were $40 \%$ higher than SEBAL and 21\% higher than SSEB. The mean annual $\mathrm{ET}_{\mathrm{a}}$ estimated for the whole estate were $107 \mathrm{Mm}^{3}$, $140 \mathrm{Mm}^{3}$, and $178 \mathrm{Mm}^{3}$ using SEBAL, SSEB and $\mathrm{SSEB}_{\mathrm{op}}$, respectively (table 2) and the mean annual PET was $219 \mathrm{Mm}^{3}$.

Table 2. Monthly and annual average actual ET for Wonji Shoa sugar cane Estate using different algorithms

\begin{tabular}{|c|c|c|c|c|c|c|}
\hline \multirow[t]{2}{*}{ Month } & \multicolumn{2}{|l|}{ SSEBAL } & \multicolumn{2}{|l|}{ SSEB } & \multicolumn{2}{|l|}{$\mathrm{SSEB}_{\mathrm{op}}$} \\
\hline & $\mathrm{mm} / \mathrm{day}$ & $\mathrm{mm} / \mathrm{month}$ & $\mathrm{mm} /$ day & $\mathrm{mm} / \mathrm{month}$ & $\mathrm{mm} /$ day & $\mathrm{mm} / \mathrm{month}$ \\
\hline January & 2.88 & 11 & 3.45 & 13 & 4.88 & 18 \\
\hline February & 2.82 & 10 & 3.01 & 11 & 3.95 & 15 \\
\hline September & 2.31 & 8 & 2.46 & 9 & 2.92 & 11 \\
\hline October & 1.57 & 6 & 3.62 & 13 & 4.18 & 15 \\
\hline Average & 2.39 & 8.75 & 3.14 & 11.5 & 3.98 & 14.75 \\
\hline Annual ETa $\left(\mathrm{Mm}^{3}\right)$ & \multicolumn{2}{|c|}{107} & \multicolumn{2}{|c|}{140} & \multicolumn{2}{|c|}{178} \\
\hline
\end{tabular}

The required timing and amount of applied water for the sugarcane were calculated based upon the prevailing climatic conditions, growing season, growing and harvesting date, root depth, and allowable depletion, soil physical properties, availability of water resources, field water losses and useful rainfall and therefore the CWR and irrigation water requirement (IR) of sugarcane crop were computed by considering the field water balance in the crop root zone. The total CWR, IR and effective rain for January and March planted sugarcane were estimated to be $2468.8,2061.6$ and $423.8 \mathrm{~mm} / \mathrm{yr}$ and $2281.9,1851.0$ and $437.8 \mathrm{~mm} / \mathrm{yr}$ respectively.

3.3 Relationship of Land Surface Temperature(LST) and NDVI in 2002

Figure 6 shows the subset images of the study area created using the tool with natural (true) color combination of Band 5, Band 4, and Band 3 correspondingly. This helps to distinguish the distribution of NDVI, LST and ET between different land covers and land features. The figures show Awash River and water storage reservoirs marked with blue color, the sugarcane estate covered by sugarcane crop is marked by dark green color, uncultivated irrigated wet fields are seen as black color and bare agricultural areas are marked by light pink color (figure 6). 

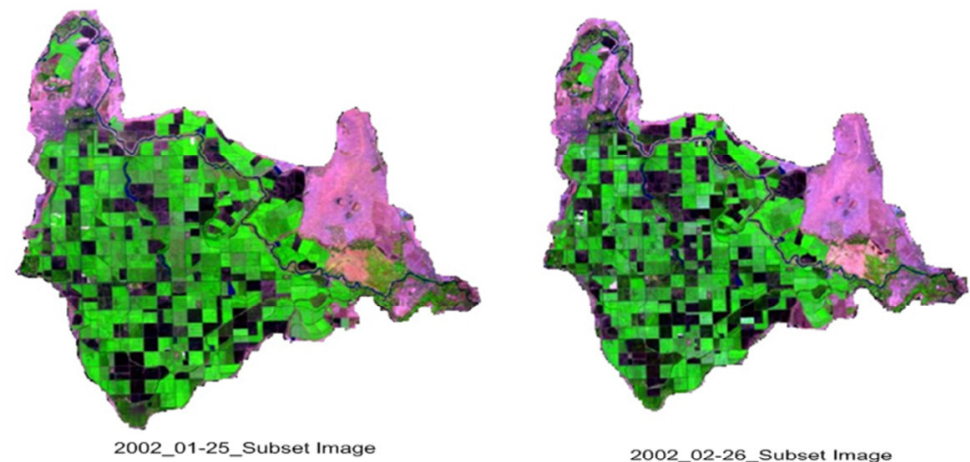

2002_02-26_Subset Image
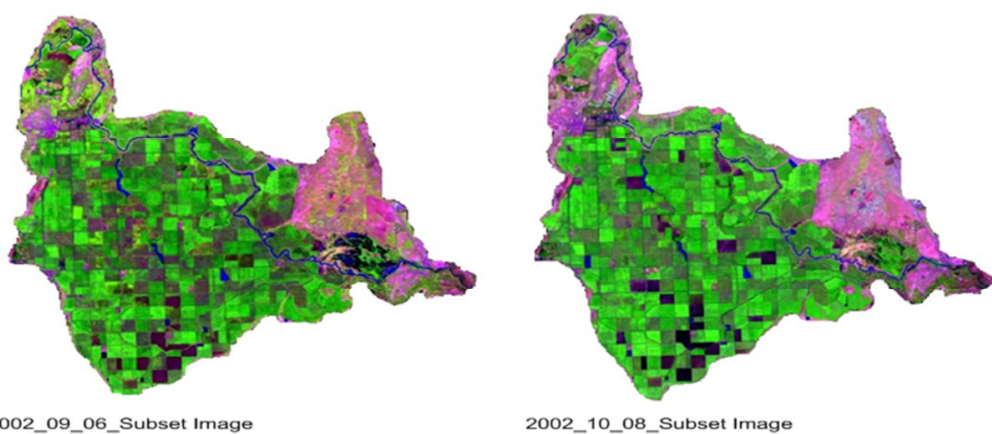

Figure 6. Land cover and features subset images of Wonji Shewa sugarcane estate

The main purpose of this comparison was to show the spatiotemporal variability of land surface temperature which varies with the available moisture on the sugarcane farms, water bodies and vegetation surfaces and it was found to be strongly dependent on the season and moisture availability. Most of the agricultural fields covered by sugarcane plantation and the water storage reservoirs exhibit lower land surface temperature than bare agricultural fields in all images generated and the influence of moisture status was also clearly noted. The images from the predominantly hotter and drier pixels contrast well with the generally cooler and wetter surface covers. There is good linear relationship between NDVI and LST with an $\mathrm{r}^{2}$ value of Jan, Feb, Sept, and Oct images of $0.72,0.704,0.38$, and 0.60 , respectively (table 3 ).

Table 3. Mean daily temperature and NDVI values of selected days in 2002.

\begin{tabular}{|l|c|c|c|c|c|}
\hline \multirow{3}{*}{ Parameters } & \multirow{2}{*}{ Statistics } & \multicolumn{4}{|c|}{ Image dates } \\
\cline { 2 - 6 } & & January 25 & February 26 & September 06 & October 08 \\
\hline \multirow{4}{*}{ LST(K) } & Minimum & 291 & 297 & 297 & 296 \\
\cline { 2 - 6 } & Maximum & 313 & 325 & 319 & 324 \\
\cline { 2 - 6 } & Mean & 300 & 310 & 304 & 306 \\
\cline { 2 - 6 } & Standard deviation & 4.49 & 5.89 & 3.73 & 4.97 \\
\hline \multirow{3}{*}{ NDVI } & Minimum & -0.33 & -0.37 & -0.23 & -0.25 \\
\cline { 2 - 6 } & Maximum & 0.77 & 0.765 & 0.86 & 0.81 \\
\cline { 2 - 6 } & Mean & 0.314 & 0.305 & 0.42 & 0.37 \\
\cline { 2 - 6 } & Standard deviation & 0.16 & 0.15 & 0.21 & 0.20 \\
\hline
\end{tabular}

\section{Conclusions}

In this study, ET estimates were made using $\mathrm{SSEB}_{\mathrm{op}}$, SSEB, and SEBAL algorithms for the Wonji Shoa Sugarcane Estate. Landsat7 ETM+ images of four days in 2002, (i.e. January 25, February, 26, September 6 and October, 8 2002), were used and the actual ET was computed using the three algorithms. The result of this study generally demonstrates that these three algorithms could be used to provide vital information on evaporative loss and moisture condition of the sugarcane estate. It can be considered as operational and feasible methods to predict actual ET and to improve water management and modeling processes in the sugarcane estate.

The remote sensing technology can be applied for the measurement, monitoring and reporting of water use and management in irrigated agriculture like large sugarcane estates. It also helps an irrigator to know the ET rate and to apply the right amount of water at the right time to ensure that the crop is not stressed, particularly during critical stages of growth which results in improved sugarcane yield production. An estimate of actual evapotranspiration derived from remote sensing techniques has the potential to improve irrigation water use efficiency and contribute to more efficient use of our water resources and to determine regional water use while also understanding local scale influences. Potential opportunities include providing information on water used by different land uses at different times to support planning for resource allocation and management (such as 
sustainable yields) of rivers and water storages. The major findings of the study clearly showed that remote sensing can have a tremendous potential for estimating evapotranspiration and water management at farm and basin level.

The simple averaged annual actual evapotranspiration by SEBAL, SSEB and SSEBop showed that the estate losses $107,140,178$, and $80 \mathrm{Mm}^{3}$ of water per year, respectively due to ET and these values are closer to actual evaporation need to be substantiated through field measurement. Since field measurements were not done in this research, it is not possible to say one method is better than the other and we now have adapted the algorithms and before recommending any of the methods for actual use these results should be tested and validated with field measurements in different environments. The analysis of actual ET in the sugarcane estate estimated by remote sensing method revealed large spatial and temporal variability which closely followed the variability in soil moisture and land use characteristics which otherwise would have been difficult to get it using the indirect methods and the evaporative fraction (parameter determines energy partitioning) in the sugarcane estate, exhibits similar regional distribution patterns as evaporation rate in the sugarcane estate. The integration of remote sensing techniques and distributed hydrological models can produce better results.

\section{Acknowledgement}

The study was supported by the United States Agency for International Development (USAID) under the AfricaUS Higher Education Initiative - HED052-9740-ETH-11-01. The authors wishes to express his gratitude for the opportunity. I am greatly indebted to my advisors Dr. Tena Alamirew, Dr. Gabriel Senay, and Dr. Mekonnen G/ Michael for their guidance and valuable comments from the preparation of the concept until the compilation of this thesis. I also thank Prof. Junming Wang for his useful comments during the thesis preparation. I thankfully acknowledge Ethiopian Institute of Water Resources (EIWR) community and Arba Minch University for all the support I have been enjoying. I would like to express my sincere gratitude to Wonji Research and Training Center community for the support during field work. The Landsat ETM+ data were obtained from the NASA Land Processes Distributed Active Archive Center (LP DAAC), USGS/ Earth Resources Observation and Science (EROS) Center.

\section{References}

[1] H. Hemakumara, L. Chandrapala, and F. Moene, "Evapotranspiration fluxes over mixed vegetation areas measured from large aperture scintillometer," Journal of Agricultural Water Management, Vol.58, pp. 109-122, 2003.

[2] J. Burdette, N. Christopher, and D. Heeren," Evaluation of a hybrid remote sensing evapotranspiration model for variable rate irrigation management," Biological Systems Engineering: Papers and Publications. Paper 380, 2015.

[3] M. Tasumi, and R. Allen, "Satellite-based ET mapping to assess variation in ET with timing of crop development," Journal of Agricultural Water Managent,Vol.8, pp. 54-62, 2007.

[4] W. Bastiaanssen, E. Noordman, H. Pelgrum, G. Davids, B.Thoreson, R. Allen, "SEBAL model with remotely sensed data to improve waterresources management under actual field conditions," Journal of Irrig. Drain. Eng. 131, 85-93, 2005.

[5] Y.Chen, J.Xia, S.Liang, J.Feng, J.Fisher, L.Xin, X.Li, S.Liu, Z.Mad, A.Miyata, Q.Mu, L.Sun, J.Tang, K.Wang, J.Wen, Y.Xue, G.Yu, T.Zha, L.Zhang, Q.Zhang, T.Zhao, L.Zhao, and W.Yuan,"Comparison of satellite based evapotranspiration models over terrestrial ecosystems in China," Remote Sensing of Environment, 140, 279-293, 2014.

[6] S. Vanino, G. Pulighe, P. Nino, C. Michele, S. Falanga and G. D’Urso, "Estimation of evapotranspiration and crop coefficients of Tendone Vineyards using multi-sensor remote sensing data in a Mediterranean environment," Journal of Remote Sensing, Vol. 7, pp. 14708-14730, 2015.

[7] H. Nouri, S. Beecham, F. Kazemi, A. Hassanli, and S. Anderson," Remote sensing techniques for predicting evapotranspiration from mixed vegetated surfaces," Hydrology and Earth System Sciences, Vol. 10, 3897-3925, 2013

[8] G. Melaku, "The impact of snail control on the prevalence and intensity of schistosomiasis mansoni in Finchaa and Wonjishoa sugar estates:Post-pilot control analysis," MSc thesis, Addis Ababa University, pp.1-74, 2009.

[9] M. Girma, and B. Awulachew, "Irrigation Practices in Ethiopia: Characteristics of Selected Irrigation Schemes," Working Paper Vol.124, pp. 1-84, 2007.

[10] B. Shimelis, "Stream flow simulation for the upper upper Awash basin," MSc. thesis,Addis Ababa university, pp. 7, 2004.

[11] R. Allen, M. Tasumi, R. Trezza, R. Waters, W. Bastiaanssen, " Surface Energy Balance Algorithms for Land: Idaho Implementation," Advanced Training and Users Manual, 7-39, 2002.

[12] C. Coll, J. M. Galve, J. M. Sánchez, and V. Caselles, "Validation of Landsat-7/ETM+ Thermal-Band 
Calibration and Atmospheric Correction with Ground-Based Measurements", IEEE Trans. Geosci. Remote Sens., vol. 48, no. 1, pp. 547-555, 2010.

[13] Sobrino, J. A., Raissouni, N., \& Li, Z. -L. (2001). A comparative study of land surface emissivity retrieval from NOAA data. Remote Sensing of Environment, 75, 256- 266.

[14] W. Bastiaanssen, M . Ud-din-Ahmed, and Y. Chemin, "Satellite surveillance of evaporative depletion across the Indus Basin," Journal of Water Resources,vol. 38 (12), pp. 1273-1282, 2002.

[15] W. Bastiaanssen, "SEBAL-based sensible and latent heat fluxes in the irrigated Gediz Basin, Turkey," Journal of Hydrology, vol. 229, pp. 87-100, 2000.

[16] G. Senay, M. Budde, J. Verdin, "Enhancing the Simplified Surface Energy Balance (SSEB) approach for estimating landscape ET: Validation with the METRIC model," Agricultural Water Management, vol. 98, pp. 606-618, 2011.

[17] R. Allen, L. Pereira, D. Raes, and M. Smith, "Crop evapotranspiration: guidelines for computing crop water requirements in United Nations FAO, Irrigation and Drainage Paper 56, FAO, Rome, Italy,", 1998.

[18] G. Senay, S. Bohms, R. Singh, P. Gowda, N. Velpuri, H. Alemu and J. Verdin, "Operational evapotranspiration mapping using remote sensing and weather datasets: a new parameterization for the SSEB approach," Journal of American Water Resources Research, In Press, 2013.

[19] W. Bastiaanssen, M. Menenti, M. Feddes, and R. Holtslag, "A remote sensing surface energy balance algorithm for land (SEBAL): formulation," Journal of Hydrology, vol. 212(213), pp. 213-229, 1998.

[20] R. Allen, M. Tasurmi, A. Morse, and R. Trezza, "A Landsat-based Energy Balance and Evapotranspiration Model in Western US Water Rights Regulation and Planning," Journal of Irrigation and Drainage Systems, vol. 19 (3-4), pp. 251-268, 2005.

[21] H. Nouri, E. Glenn, S. Beecham, S. Chavoshi, P. Sutton, S. Alaghmand, B. Noori, and P. Nagler," comparing three approaches of evapotranspiration estimation in mixed urban vegetation: field-based, remote sensing-based and observational-based methods," Journal of Remote Sensing, Vol. 8, 492, 2016. 